\title{
Biomass and population structure of a large aggregation of krill near Prydz Bay, Antarctica
}

\author{
I. R. Higginbottom, G. W. Hosie
}

Australian Antarctic Division, Channel Highway, Kingston, 7050 Tasmania, Australia

\begin{abstract}
A dense aggregation of krill Euphausia superba in the region of Prydz Bay, Antarctica, was investigated in March 1987 using hydroacoustic and net sampling techniques. Maximum aggregation density was estimated to be $1530 \mathrm{~g} \mathrm{~m}^{-3}$; total biomass 57000 tonnes wet weight. This is the first reported observation of an aggregation of this magnitude in the Prydz Bay region. The aggregation is also unique in that it consisted mainly of very large sexually immature males, the majority 48 to $58 \mathrm{~mm}$ in body length.
\end{abstract}

Large aggregations of krill have been reported commonly in the region of the Antarctic Peninsula but not in the Indian or Pacific regions of the Southern Ocean. None have been reported in the region of Prydz Bay. Large aggregations are attractive targets for predators, including the commercial krill fishery, and contain a large but unknown proportion of the total biomass of krill within a given region (Mauchline 1981, Mathisen \& Macauley 1983).

During the course of an acoustic and net survey to estimate the abundance of krill in the Prydz Bay region a concentration of Antarctic krill Euphausia superba Dana was found before dawn on 9 March 1987 in the vicinity of Cape Darnley, near Prydz Bay lechogram, Fig. 1). The concentration extended for $11 \mathrm{~km}(6 \mathrm{n}$ miles) and contained within it a relatively dense aggregation, at $66^{\circ} 53.5^{\prime} \mathrm{S}, 70^{\circ} 15.5^{\prime} \mathrm{E}$. Preliminary results of opportunistic net-based and hydroacoustic investigations into the size, density structure and population structure of the dense aggregation are presented.

Methods. Density structure and extent of the area of high density referred to as the 'swarm' were mapped acoustically. First contact with the swarm was made at 21:03 h GMT (8 March), and all surveying, including net sampling, was completed at 02:58 h GMT (9 March). A Simrad EKS-120 echosounder operating at $120 \mathrm{kHz}$ and a Simrad QD echointegrator were used to determine the krill biomass. The echosounder was calibrated before the cruise by Simrad Subsea in Horten, Norway, and the source level plus the receiving sen- sitivity was $110.1 \mathrm{~dB}$. Instrument settings of the echosounder were: range 0 to $250 \mathrm{~m}$, pulse duration 0.6 ms, receiver bandwidth $3 \mathrm{kHz}$, gain $0 \mathrm{~dB}$, time-varied gain function $20 \log R$, time-varied gain range 3 to 100 $\mathrm{m}$, equivalent beam width $-18.0 \mathrm{~dB}$ re. 1 steradian, echosounder constant ' $\mathrm{C}$ ' $-40.5 \mathrm{~dB}$ and recorder mode 'normal'. The technique of echo-integration (Johannesson \& Mitson 1983) was used to estimate krill biomass. A detailed description of the echosounding equipment on board MV 'Nella Dan' and a summary of the echointegration technique (including a discussion of errors inherent in the technique) is given in Higginbottom et al. (1988). The acoustic parameter mean volume back-

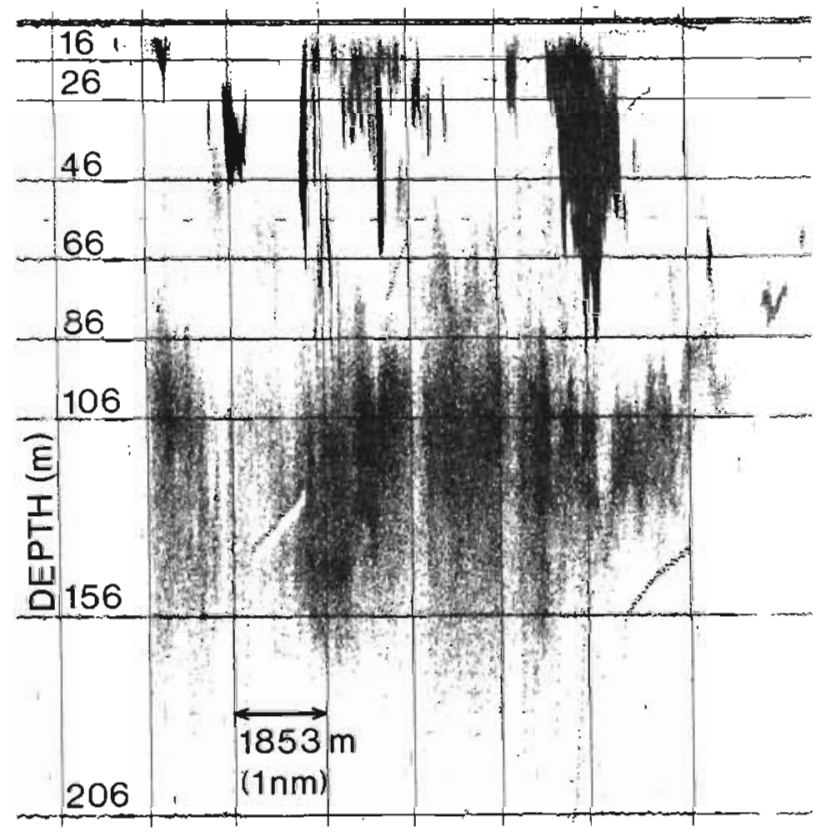

Fig. 1. Euphausia superba. Echogram $(120 \mathrm{kHz})$ of first contact of krill 'concentration' including the dense aggregation ('swarm'). The diffuse aggregation below the swarm is clearly seen 
scatter strength (MVBS) was recorded at $370 \mathrm{~m}(0.2 \mathrm{n}$ mile) intervals in 7 vertical layers $(7-16,16-26,26-46$, $46-66,66-86,86-106$, and $106-156 \mathrm{~m})$ referenced to the sea surface. Compensation for sound attenuation applied to the 106-156 m layer, which was beyond the range of the electronic time varied gain function, was calculated for the $106 \mathrm{~m}$ depth.

The mean target strength (TS) of krill in the swarm was estimated from the mean backscattering cross section of krill in the subsample (Higginbottom et al. 1988), where the target strength of an individual krill is given by TS $=19.9 \log (\mathrm{l})-95.7$ (Anonymous $1986 ; \mathrm{l}=$ krill length in $\mathrm{mm}$ ). Mean weight of krill in the swarm was estimated by mean weight of krill subsampled from the net hauls (see below).

The survey was carried out along a cruise track that included 5 transects arranged in a modified 'manoverboard' search pattern (Watkins et al. 1986) (Fig. 2). The mean krill number- and weight-densities were calculated from the acoustic data for each integration interval. Average density of the swarm was then estimated using the 'ratio estimator' (Anonymous 1986), assuming that the 5 transects provided independent estimates of the swarm density. Size and shape of the swarm were estimated by contouring point densities representing the mean krill density along an integration interval in the $100 \mathrm{~m}$ of water column below the transducer. Data were contoured using the NCAR CONRAN plotting package (National Centre for Atmospheric Research, Boulder, Colorado), with additional smoothing done by hand. The swarm edge was defined as the $10 \mathrm{~g} \mathrm{~m}^{-3}$ contour.

Krill were sampled using a Rectangular Midwater Trawl RMT8 (4.5 mm mesh) (Baker et al. 1973). Towing speed was $1 \mathrm{~m} \mathrm{~s}^{-1}$ (2 knots), resulting in an effective mouth area of $8 \mathrm{~m}^{2}$ (Roe et al. 1980). The net was equipped with a flowmeter, a combined electronic/ mechanical net release and a depth monitor that was connected to a real-time read out on deck. Thus the net could be opened and closed at precise positions within the swarm.

Two horizontal hauls were carried out. The first haul sampled the swarm at a depth of $25 \mathrm{~m}$, for $10 \mathrm{~min}$, where the echosounder indicated that the swarm extended from 13 to $55 \mathrm{~m}$ (Fig. 2, Haul A). The second haul sampled a deeper more diffuse aggregation of krill situated under the swarm (Fig. 1). The net was opened for $10 \mathrm{~min}$ at $130 \mathrm{~m}$ (Fig. 2, Haul B). The net hauls were made between 21:55 and 23:45 h GMT and before the swarm was mapped acoustically.

On deck krill from the swarm catch were emptied into 6 bins of 40 to $60 \mathrm{l}$ capacity. A randomly selected sub-sample was taken, a handful at a time, from the 6 bins and totalled 629 individual krill. All specimens were preserved in $10 \%$ Steedman's solution (Steedman 1976) for subsequent examination at the Australian Antarctic Division in Hobart. Body length (Standard 1, measurement; Mauchline 1980) was measured to $0.1 \mathrm{~mm}$ accuracy, and body wet weight was measured to $0.001 \mathrm{~g}$ accuracy. Male and female krill were classified into maturity stages according to the system of Makarov \& Denys (1981).

Results. The swarm was positioned above a submarine hill which rose $105 \mathrm{~m}$ relatively steeply from the west and fell away more gently to the north and east in the vicinity of the swarm (Fig. 3). A diffuse and apparently separate aggregation of much lower density was distinguishable below the main aggregation (Fig. 1). The survey cruise track, the positions of net hauls and the radial transects of the 'man overboard' search are plotted in Fig. 2. The area of the swarm within the $10 \mathrm{~g}$ $\mathrm{m}^{-3}$ isopleth was estimated to be $5.7 \mathrm{~km}^{2}\left(1.7 \mathrm{n}\right.$ miles $\left.{ }^{2}\right)$. Speed and direction of the apparent sea surface current were estimated by the 'drift' and 'set' from 11 satellite position fixes from a Magnavox satellite navigator. The speed of the apparent current ranged from 0.05 to 0.3 $\mathrm{ms}^{-1}(0.1$ to $0.6 \mathrm{knots})$, and the direction ranged from 6 to $97^{\circ}$ (Fig. 3). During the same period the wind came

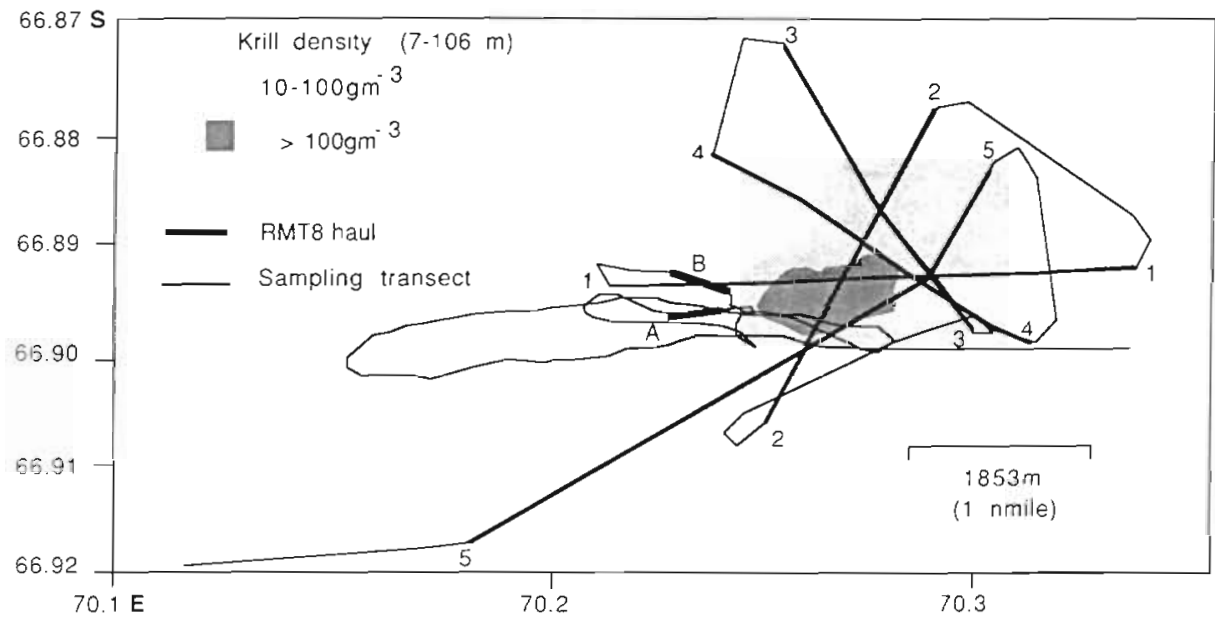

Fig. 2. Euphausia superba. Swarm shape indicated by $10 \mathrm{~g}$ $\mathrm{m}^{-3}$ isopleth in relation to cruise track. Sampling transects are highlighted and numbered; locations of the target trawls are labeled ' $\mathrm{A}$ ' and ' $\mathrm{B}$ ' 
Fig. 3. Euphausia superba. Swarm shape in relation to local bathymetry. Apparent direction and magnitude of the sea surface current indicated by arrows at the position of each of 11 satellite fixes

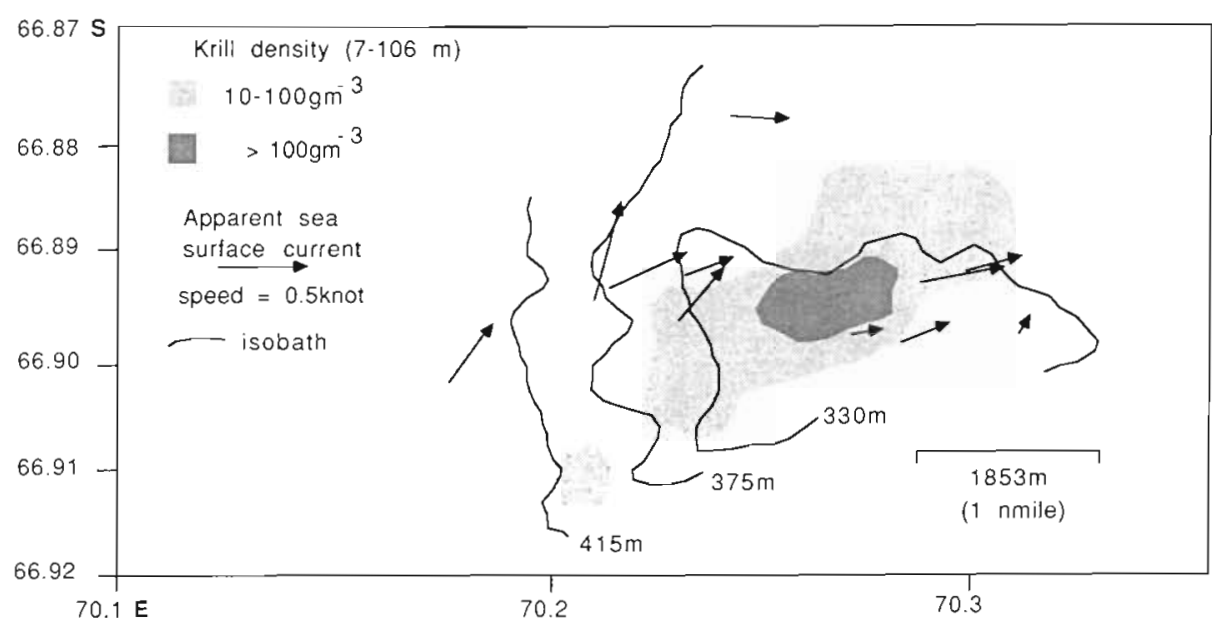

aggregation ranged from about 80 to $170 \mathrm{~m}$ in depth and was some 3000 times less dense.

Inspection of successive echograms suggested that the swarm was moving downward in the water column over the period of observation. To further investigate this trend the proportion of krill in each layer was plotted against time (Fig. 6). While this plot also suggests that the krill were moving downward, there is no evidence to suggest that the swarm was aggregating or that it had been dispersed overnight.

The average krill density observed along each of the 5 radial transects is shown in Table 1. Mean transect biomass ranged from $44.4 \mathrm{~g} \mathrm{~m}^{-3}(-59.1 \mathrm{~dB})$ to $182 \mathrm{~g}$ $\mathrm{m}^{-3}(-40.2 \mathrm{~dB})$. Maximum biomass recorded was 1534 $\mathrm{g} \mathrm{m}^{-3}$ (MVBS $=-30.9 \mathrm{~dB}$ ) averaged over a $20 \mathrm{~m}$ depth

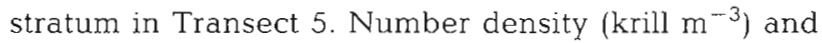
biomass $\left(\mathrm{g} \mathrm{m}^{-3}\right)$ estimates for the swarm as a whole and krill biomass, based on all transects, lay between and $85 \mathrm{~m}$. No krill were seen at the surface. The deeper proportion of the sample volume occupied by the swarm, or by changes in the density of krill within the swarm per se. The swarm extended from a minimum of $7 \mathrm{~m}$ to a maximum of $111 \mathrm{~m}$ depth, and the bulk of the

Integration interval number (each interval 0.2 nautical miles long)

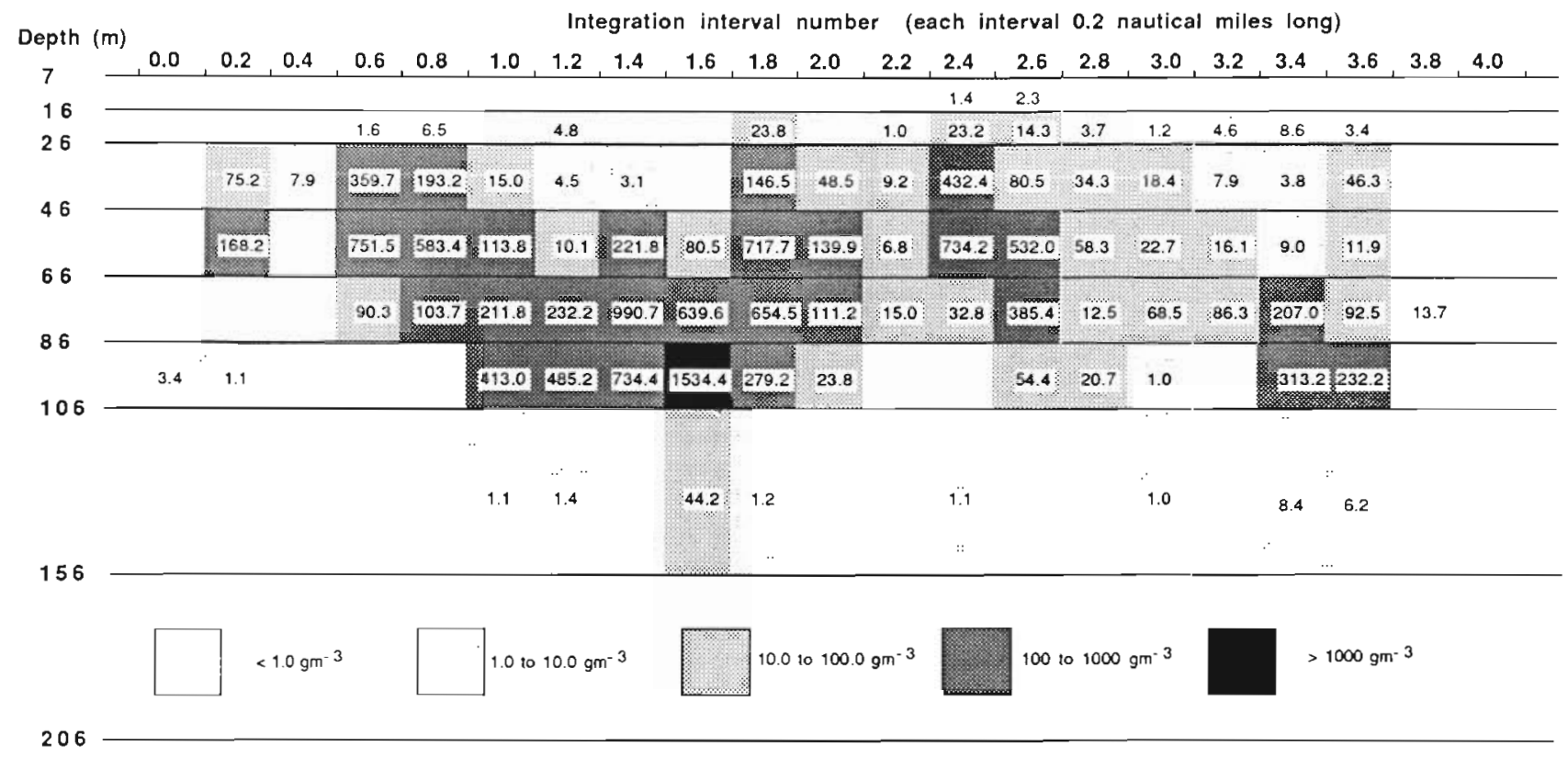

Fig. 4. Euphausia superba. Vertical profile of krill density along Transect 5 


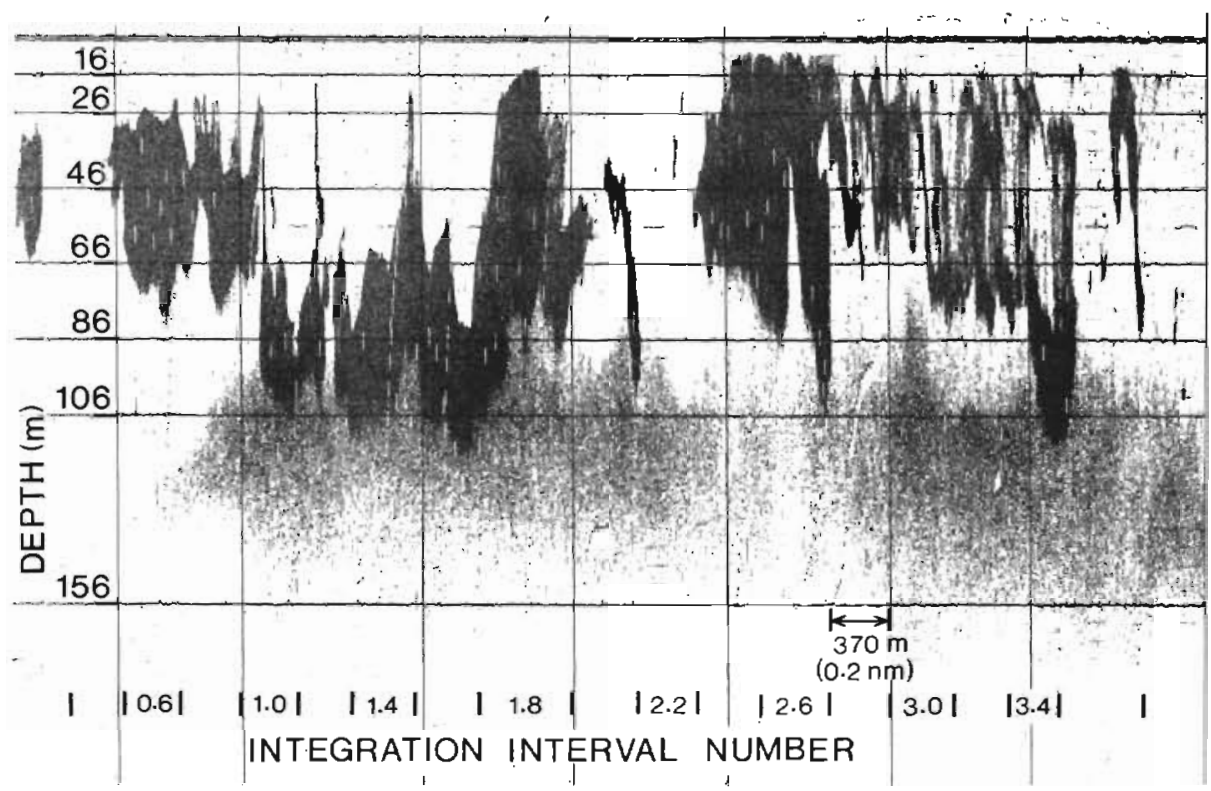

Fig. 5. Euphausia superba Echogram $(120 \mathrm{kHz})$ along for the deeper aggregation are given in Table 2. Total biomass of the swarm was estimated from the 5 transect means to be 57000 tonnes with a standard deviation of 20000 tonnes.

Total wet weight of krill caught during the RMT8 haul through the swarm was $294 \mathrm{~kg}$. This amount of krill clogged the last 2 to $3 \mathrm{~m}$ of the net. No other species were observed in this haul. Prior to this haul the largest catch by Australian scientists with an RMT8 was $27.4 \mathrm{~kg}$ of krill caught in a 33 min haul in December 1982 (Williams et al. 1986). Only 127 individual krill were caught in the RMT8 haul through the deeper aggregation.

Males comprised $79.8 \%$ of the krill sub-sample from the swarm catch, and of these the major component was large immature (2M) males (Figs. 7 and 8). By contrast, the deeper aggregation had a much greater component of juveniles $(40.5 \%)$ and sub-adults, and a more even distribution of body sizes. The mean target strength and mean weight of krill in the sub-sample were estimated to be $-62.5 \mathrm{~dB}$ and $1.06 \mathrm{~g}$ respectively.
Discussion. The mean density of the swarm $1101 \mathrm{~g}$ $\mathrm{m}^{-3}$ ) is 2 orders of magnitude larger than the most dense aggregation observed either acoustically or by nets on any of 6 previous Antarctic Division cruises. Mean density is of the same order as the mean density of $80 \mathrm{~g} \mathrm{~m}^{-3}$ observed in a super-swarm near Elephant Is. in 1983 (Mathisen \& Macaulay 1983). Maximum density recorded within the swarm was $1530 \mathrm{~g} \mathrm{~m}^{-3}$ averaged over a layer $20 \mathrm{~m}$ deep and $370 \mathrm{~m}$ long. Maximum densities recorded previously on Antarctic Division cruises were $1.7 \mathrm{~g} \mathrm{~m}^{-3}$ estimated acoustically (Higginbottom et al. 1988) and $1.7 \mathrm{~g} \mathrm{~m}^{-3}$ estimated by net haul (Hosie et al. 1988). The maximum density observed in the swarm is low compared to the range of swarm densities of 1 to $33 \mathrm{~kg} \mathrm{~m}^{-3}$ reported by Everson. (1977).

The observation that the swarm was above a submarine hill is consistent with the observations of Witek et al. (1981) who observed that large krill concentrations are often found where currents were modified by bottom elevations. There was little evidence,

TIME (GMT)

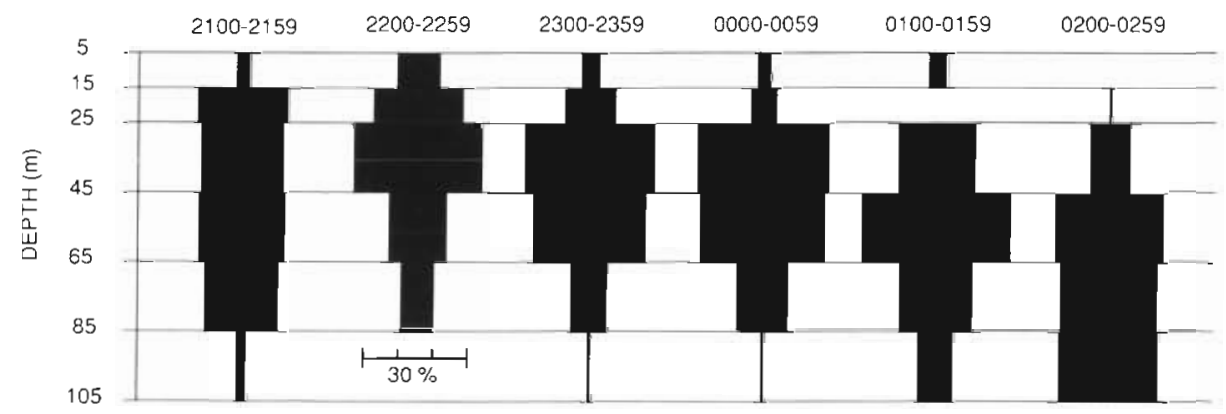

Fig. 6. Euphausia superba. Vertical distribution of krill biomass for each hour of the survey 
Table 1. Euphausia superba. Mean and maximum krill densities $\left(\mathrm{g} \mathrm{m}^{-3}\right)$, and mean volume backscattering strength [dB], observed along the 5 survey transects. Densities were calculated for each integration interval prior to estimating the transect mean

\begin{tabular}{|lcrrr|}
\hline $\begin{array}{l}\text { Transect } \\
\text { number }\end{array}$ & $\begin{array}{c}\text { Length } \\
\mathrm{km}(\mathrm{nm})\end{array}$ & $\begin{array}{c}\text { Maximum density } \\
\mathrm{g} \mathrm{m}^{-3}[\mathrm{~dB}]\end{array}$ & $\begin{array}{c}\text { Mean density } \\
\mathrm{g} \mathrm{m}^{-3}[\mathrm{~dB}]\end{array}$ \\
\hline 1 & $3.7(2.0)$ & $544[-35.4]$ & $44.4[-59.1]$ \\
2 & $4.1(2.2)$ & $306[-37.9]$ & $32.2[-60.5]$ \\
3 & $4.4(2.4)$ & $351[-37.3]$ & $57.6[-45.1]$ \\
4 & $4.4(2.4)$ & $1013[-32.7]$ & $133.1[-41.5]$ \\
5 & $7.8(4.2)$ & $1534[-30.9]$ & $181.8[-40.2]$ \\
\hline
\end{tabular}

Table 2. Euphausia superba. Estimates of density within the swarm, including a comparison of acoustic estimates during the haul with simultaneous net haul estimates

\begin{tabular}{|lcc|}
\hline Estimate & $\begin{array}{c}\text { Density } \\
\left.\text { (no. } \mathrm{m}^{-3}\right)\end{array}$ & $\begin{array}{c}\text { Density } \\
\left(\mathrm{g} \mathrm{m}^{-3}\right)\end{array}$ \\
\hline $\begin{array}{l}\text { Mean of acoustic intervals on } \\
5 \text { transects }\end{array}$ & 94.7 & 100.8 \\
Net haul in swarm (25 m) & 48.1 & 51.2 \\
$\begin{array}{l}\text { Net haul in deeper aggregation } \\
(130 \mathrm{~m})\end{array}$ & 0.023 & 0.0157 \\
$\begin{array}{l}\text { Acoustic intervals during } \\
\text { and around net haul in swarm } \\
(16-46 \mathrm{~m})\end{array}$ & 213.3 & 227.0 \\
\hline
\end{tabular}
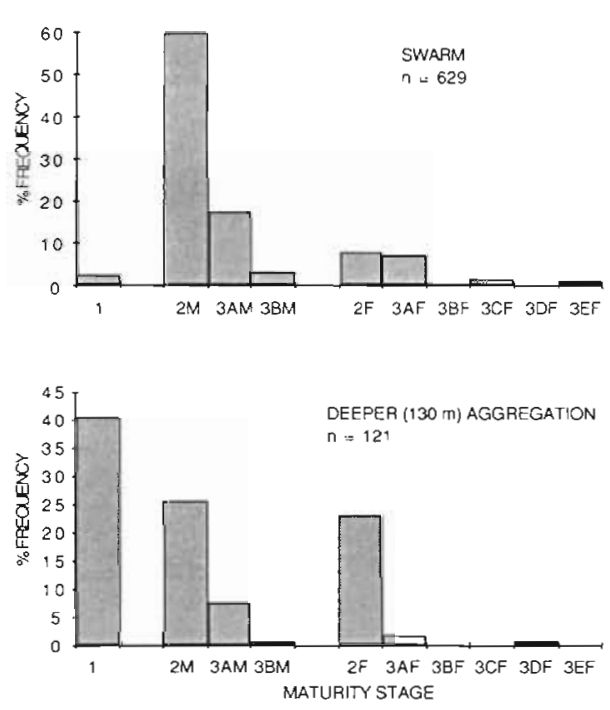

Fig. 7. Euphausia superba. Percentage-frequency distribution of maturity stages for the swarm and deeper $(130 \mathrm{~m})$ aggregation. $1=$ juveniles; $2 \mathrm{M}=$ sub-adult (immature) male; $3 \mathrm{AM}=$ mature male, no spermatophore in ampullae; $3 \mathrm{BM}=$ mature male with spermatophore, ready to mate; $2 \mathrm{~F}=$ sub-adult (immature) female; $3 \mathrm{AF}=$ mature female not mated; $3 \mathrm{BF}=$ mated mature female, ovaries small; $3 \mathrm{CF}=$ mated mature female, ovaries fill thoracic space; $3 D F=$ mated mature female, carapace swollen with enlarged ovaries, i.e. spawning female; $3 \mathrm{EF}=$ spent fenale though, in the present study, to indicate that the swarm was static over the hill. Neither was there clear evidence that the swarm, in its entirety, was moving with the current. The derived shape of the swarm was elongated along the line of flow (Fig. 2), possibly a result of the time difference between the acoustic transects, suggesting west-east movement. Equally, however, a current up to 0.6 knots $\left(3 \mathrm{~m} \mathrm{~s}^{-1}\right)$ could be expected to have carried the swarm out the study area during the 6 h of this study

The high proportion (80\%) of males within the swarm is not unusual. Wide variations in the sex ratio have been observed in aggregations of a number of euphausiid species (see review by Nicol 1984). For example, Nemoto et al. (1981) observed swarms of Euphausia superba with sex ratios in the range 0 to $100 \%$ female. Females, however, predominated in most swarms by 60 to $70 \%$ (Nemoto et al. 1981). Watkins et al. (1986) observed a number of swarms of $E$. superba comprising more than $70 \%$ males in the Atlantic sector. A unique feature of the large Prydz Bay aggregation was the very high proportion of large immature males, i.e. males with undeveloped petasmae. These males are comparable in body size with the
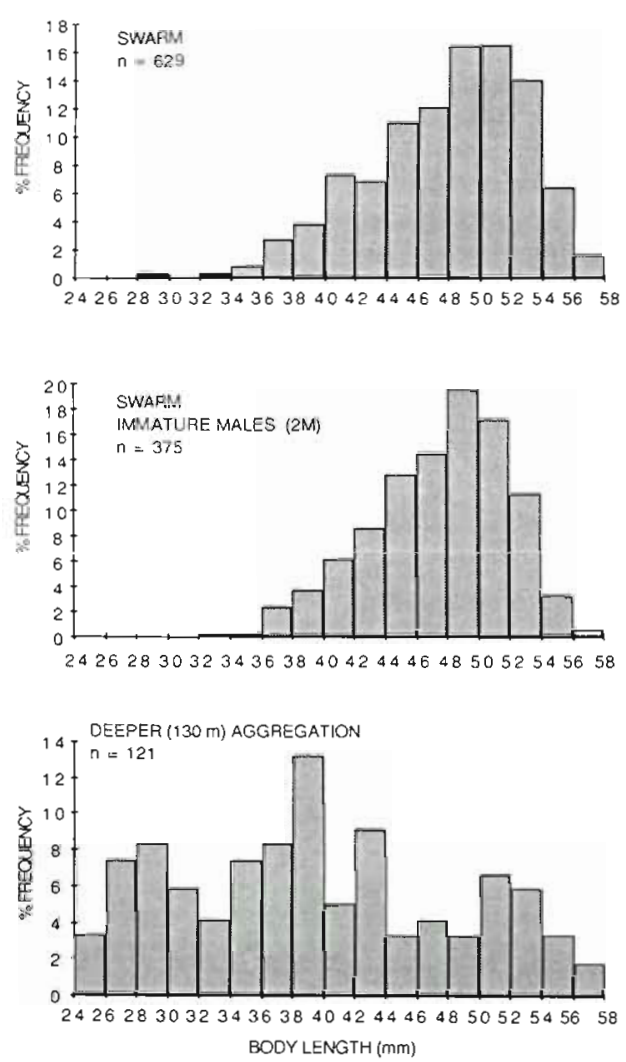

Fig. 8. Euphausia superba. Percentage size-frequency distribution, all maturity stages combined, for the swarm and deeper $(130 \mathrm{~m})$ aggregation, as well as for immature males (2M) collected from the swarm 
specimens identified as Year 3t, 4t and 5+ agegroups by Siegel (1986) and Hosie et al, (1988) which were considered to be sexually mature after $3 \mathrm{yr}$ Laboratory-based observations (Ikeda 1987) have confirmed that krill reach full sexual maturity after 3 yr and have shown that females are capable of regressing in external sexual characteristics at the end of the spawning period (Thomas \& Ikeda 1987). The presence of a large number of large sexually immature males in March, close to the end of the spawning period in Prydz Bay (Hosie et al. 1988), suggests that males are also capable of post-reproductive sexual regression. The $80 \%$ bias of males also supports the suggestion of Nemoto et al. (1981) that there may be a separation of sexes after mating and spawning occur.

The problems of determining the biomass of a species that aggregates are highlighted by the fact that this is the first description of an aggregation of such large magnitude in the region of Prydz Bay. A $20 \mathrm{~km}$ long aggregation was detected acoustically during the Australian FIBEX (Kerry \& Higginbottom unpubl.) cruise but its biomass and composition were not determined. Large areas of low or no abundance and small areas of high abundance (Higginbottom et al. 1988, Hosie et al. 1988), lead to problems in the statistical analysis of the data, e.g. variances that exceed the mean by a large extent (Nast 1982, Siegel 1985, Millex 1986, Hosie et al. 1988). Sample sizes which are small in comparison to the area being surveyed also contribute to high variances and hence to wide confidence limits on biomass estimates.

The biomass (57000 tonnes) of this single dense aggregation represents $1.3 \%$ of the total biomass estimated for the region of Prydz Bay during January 1985 (Higginbottom et al. 1988), yet the aggregation occupied an area of only $7 \mathrm{~km}^{2}$ out of 1.3 million $\mathrm{km}^{2}$ of ocean in the region. This suggests that large aggregations may contain a substantial proportion of the biomass of krill in the region. These findings also reinforce the suggestions of Mackintosh (1966). Mauchline (1981) and Macaulay et al. (1984) that large dense aggregations must be considered separately from routine transect data when estimating biomass.

Acknowledgements. We thank Dr K. E. Kerry and Dr S. vicol for valuable comments on the manuscript. We thank the officers and crew of the MV 'Nella Dan' for their assistance in the field, and in particular Captain A. Dethlef for navigation during the swarm study.

\section{LITERATURE CITED}

Anonymous (1986). Post-FIBEX Data Interpretation Workshop. Frankfurt. Federal Republic of Germany, September 1984. BIOMASS Report Ser. 40: 1-106
Baker, A. de C.. Clarke, M. R., Harris, M. J. (1973). The NIO combination net (RMT $1+8$ ) and further developments of rectangular midwater trawls. J. mar. biol. Ass. U. K. 53: $167-184$

Everson., I. (1977). The living resources of the Southern Ocean. Food and Agricultural Organisation of the United Nations, United Nations Development Program, Rome. F.A.O. Fish. Rep. CLO/SO/77/1: 1-156

Everson, I, Murphy, E. (1987). Mesoscale variability in the distribution of krill Euphausia superba. Mar. Ecol. Prog. Ser. 40: 53-60

Higginbottom, I. R., Kerry, K. R., Wayte, S. E. (1988). The distribution and abundance of krill in the region of Prydz Bay, Antarctica. A report of the hydroacoustic surveys carried out on the research cruises FIBEX, ADBEX-II and SIBEX-II. ANARE Res. Notes 62: 1-46

Hosie, G. W., Ikeda, T., Stolp, M. (1988). Distribution, abundance and population structure of the antarctic krill (Euphausia superba Dana) in the Prydz Bay region, Antarctica. Polar Biol 8: 213-224

Ikeda, T (1987). Mature krill (Euphausia superba Dana) grown from eggs in the laboratory. J. Plankton Res. 9: $565-567$

Johannesson, K. A., Mitson, R. B. (1983). Fisheries acoustics. A practical manual for aquatic biomass estimation. F.A.O. Fish. tech. Pap. 240: 1-249

Macaulay, M. C., English, T S., Mathisen, O. A. (1984). Acoustic characterization of swarms of Antarctic krill (Euphausia superba) from Elephant Island and Bransfield Strait. J. Crustcean Biol. 4 (Spec. No. 1): 16-44

Mackintosh, N. A. (1966). The swarming of krill and problems of estimating the standing stock. Norsk Hvalfangsttid. 55: 213-216

Makarov, R. R., Denys, C. J. (1981). Stages of sexual maturity of Euphasia superba Dana. BIOMASS Handb. Ser. 11 $1-13$

Mathisen, O. A., Macaulay, M. C. (1983). The morphological features of a super swarm of krill, Euphausia superba Mem. natin. Inst. polar Res. (Spec. Issue) 27: 153-164

Mauchline, J. (1980). Measurements of body length of Euphausia superba Dana. BIOMASS Handb. Ser. 4: 1-9

Mauchline, J. (1981). Studies on patches of krill, Euphausia superba Dana. BIOMASS Handb. Ser 6: 1-36

Miller, D. G. M. (1986). Results from biological investigations of krill (Euphausia superba) in the Southern Indian Ocean during SIBEX I. Mem natln. Inst. polar Res. (Spec. Issue) 40: $1.17-139$

Nast, F. (1982). The assessment of krill (Euphausia superba Dana) biomass from a net sampling programme. Meeresforsch. 29: 154-165

Nemoto, T., Doi, T., Nasu, K. (1981). Biological characteristics of krill caught in the Southern Ocean. In: BIOMASS Vol. II. Selected contributions to the Woods Hole Conference on living resources of the Southern Ocean, 1976. SCAR, Cambridge, p. $47-64$

Nicol, S. (1984). Population structure of daytime surface swarms of the euphausiid Meganyctiphanes norvegica in the Bay of Funday, Mar. Ecol. Prog. Ser. 18: 241-251

Roe, H. S. J., Baker, A de C., Carson, R. M., Wild, R., Shale, D. M. (1980). Behaviour of the Institute of Oceanographic Science's rectangular midwater trawls: theoretical aspects and experimental observations. Mar. Biol. 56: 247-259

Siegel, V. (1985). The distribution pattern of krill, Euphausia superba, west of the Antarctic Peninsula in February 1982 Meeresforsch. 30: 292-305

Siegel, V (1986). Untersuchungen zur Biologie des antarktischen Krill, Euphausıa superba, im Bereich der Bransfield 
Straße und angrenzender Gebiete. Mitt. Inst. Seefisch. 38: $1-244$

Steedman, H. F. (1976). Zooplankton fixation and preservation. Monogr. oceanogr Methodol. 4: 1-359

Thomas, P. G., Ikeda, T (1987). Sexual regression, shrinkage, re-maturation and growth of spent female Euphausia superba in the laboratory. Mar Biol. 95: 357-363

Watkins, J. L., Morris, D. J., Ricketts, C., Priddle, J. (1986). Differ-

This note was submitted to the editor ences between swarms of Antarctic krill and some implications for sampling krill populations. Mar. Biol. 93: 137-146 Williams, R., Kirkwood, J. M., O'Sullivan, D. B. (1986) ADBEX-I cruise zooplankton data. ANARE Res. Notes 31 $1-108$

Witek, Z., Kalinowski, A., Grelowski, A., Wolnomiejske, N (1981). Studies of aggregations of krill (Euphausia superba). Meeresforsch. 28: 228-243

Manuscript first received: July 6, 1988

Revised version accepted: July 18, 1989 